\title{
'An English Barrack in the Oriental Seas'? India in the Aftermath of the First World War
}

\author{
KEITH JEFFERY \\ Ulster Polytechnic
}

DuRING the last ninety years of British rule in India, the 'Jewel of the Empire' was, as Lord Salisbury remarked in 1882 , easily regarded by many British imperialists as 'an English barrack in the Oriental Seas from which we may draw any number of troops without paying for them' ${ }^{1}$ In more prosaic terms India was seen as a permanent strategic reserve and the principal means by which British interests were secured throughout Asia, from Suez to Wei-hei-wei. As such, India was a central component in the British imperial system. The empire's matchless prestige, its wealth and apparent power all stemmed in large measure from India. In the second half of the nineteenth century the Raj, the East India trade and the Indian Army demonstrated a combination of power which Britain's imperial rivals might envy but never surpass. The central importance of India is illustrated by the Victorian conception of imperial defence, which was seen to depend on the twin pillars of naval supremacy and the defence of India. The only serious military commitment which British planners admitted before the turn of the century was the possibility of meeting a Russian invasion of India across the North West Frontier. This threat existed mostly in the minds of British generals. Britain and Russia came closest to war on the Frontier at the time of the Penjdeh incident in I 885 , but even then the likelihood of a Russian expedition against India was hardly more than remote. Nevertheless, the threat of invasion was the principal rationale for the nature and size of the Army in India and this consideration guided Lord Kitchener's reforms of the Indian Army during his time as Commander-in-Chief from 1902 to 1909 . Every effort was made to ensure rapid mobilization and to enhance mobility so that a 'Field Army' could be marshalled on the Frontier in the shortest possible time. Kitchener also made fantastic estimates of the numbers of troops required to defend the sub-continent. In 1904 he calculated that the War Office would immediately have to supply i 60,000 men to reinforce

${ }^{1}$ Sir Charles Lucas (ed.), The Empire at War (5 vols, London, 1921-26), I, pp. 56-7. 0026-749X/8 I/0406-0904\$02.0o (C) 198I Cambridge University Press. 
the 200,000-strong Army in India, and another 300,000-400,000 troops in a second year of war. ${ }^{2}$ The real effect of these calculations was to startle the British cabinet into seeking a diplomatic solution to the military problem. This they did with the Anglo-Russian Convention of 1907 which aimed to ease the burden of imperial defence by securing the frontiers of India and lifting Russian pressure from parts of the Middle East. Along with the Anglo-French entente from 1904, this marked the beginning of Britain's military 'continental commitment' and a move away from the more specifically imperial strategy of the nineteenth century. ${ }^{3}$ But so far as GHQDelhi was concerned, this shift might never have occurred. Since the Russian agreement was regarded as a snare and a delusion, Indian military planners continued to treat Russia as their principal threat. After all, armies need enemies to justify their existence. Even the most plausible Indian general could hardly explain away an army of some quarter of a million men by referring to a potential Afghan threat or the need to police restive Pathan tribesmen. Thus, in I9I 3 the Army in India remained specifically organized to meet the needs of a major war on the Frontier. Nearly two-thirds of the entire force were set aside to act as a Field Army; the remainder being earmarked for internal security. Out of a total 234,000 men, I 52,000 served in the Field Army. ${ }^{4}$ The war briefly interrupted this concern, but following the Bolshevik revolution there were renewed fears of Russian expansion. After the armistice in I 9 I 8 the Indian General Staff automatically returned to their plans for the defence of the Frontier, no more questioning the principles upon which they were based than they had done before the war.

The second principal function of the military forces in India was internal security. These forces-the 'Army in India'-comprised two parts: British units stationed temporarily in India on the 'Cardwell' system, and the British-commanded Indian Army. The Army in India was treated as a coherent whole and managed by the High Command in Delhi. The Indian Army had been established after the Mutiny, as had a proportion of approximately one British soldier to two Indian, which was generally adhered to until the outbreak of the Great War. In I9I4, for example, there were 81 , ooo British and 152,000 Indian troops. "The ratio' was a central tenet of the Indian military administration and a crude index of mistrust. Before the Mutiny the proportion of British to

2 Michael Howard, The Continental Commitment (Harmondsworth, 1974), pp. I9-20.

${ }^{3}$ For an account of this, see Howard, ibid., ch. 2.

${ }^{4}$ Government of India, The Army in India and its Evolution (Calcutta, 1924), pp. $221-2$.

5 Ibid., p. 219. 
Indian had been almost one to nine, but following it no-one had been prepared to risk continuing such a low ratio. For fifty years it remained high and unchallenged. Although by I 914 it had become well-nigh immutable, such was the demand for British units during the war that the ratio was dropped and they were drafted out at will. By November I 918 there were more than six Indian soldiers to each British. ${ }^{6}$ There is little evidence to suggest that this constituted much of a security risk. After the war, nevertheless, the Indian high command spontaneously worked to restore the pre-war ratio. Despite the fact that soldiers might excuse it not only on the grounds of internal security but also of military efficiency, Indian political opinion was unlikely to be convinced. A military organization which implied that Indians were either untrustworthy or inefficient, or both, can hardly be expected to inspire confidence or loyalty among Indians. Yet this was precisely the aim of successive Indian governments. British administrators consistently asserted the specifically Indian nature of the Indian Army and British officers strongly rejected any notion that Indian troops were mere mercenaries. These admirable attitudes were to be put to the test in 1919-22.

Another legacy from 1857 was the pattern of recruitment. It was concentrated among the 'martial races' of north India which had largely remained loyal during the Mutiny. The most favoured recruiting area was the Punjab, where Sikhs, Jats and Rajputs joined up in increasing numbers during the years leading up to the war. Between I 9 I 4 and 1918 the Punjab supplied over forty per cent of the total combatants enlisted during the war. ${ }^{7}$ Regional recruitment of this sort, initially encouraged for security reasons and later increased because northern Indians were allegedly more 'martial' than southern, was not entirely to the British advantage. The Punjab bordered on the intermittently unsettled Baluchistan and North West Frontier Province. It was also crucial to the army. So great was its strategic importance that civil administrators had to guard against straining the loyalty of their local Indian collaborators. This was particularly true after the war when Muslim unrest swept through the Punjab. Localized recruiting also provoked Indian accusa-

${ }^{6}$ i I November 1918: British, 64,023; Indian, 388,599. War Office, Statistical Abstract of Information Regarding the Army at Home and Abroad, Public Record Office (PRO) W.O.r61/82. Quoted by kind permission of Controller of H.M. Stationery Office.

${ }^{7}$ From a population approximately $15 \%$ of the Indian total. This figure was doubtless enhanced by the fact that 'Indian soldiers . . . were . . ., to face the matter quite frankly, persuaded with great vigour, in certain places, particularly in the Punjab, to join His Majesty's forces during the war'. Memo. by Montagu, 15 October 1920, PRO CAB. $24 / 112$ C.P. 1987. 
tions that the British were pursuing a policy of 'divide and rule' in India. As with the ratio, it raised questions concerning the real nature of the Indian Army and, indeed, the Indian Empire itself. If the British aim was a united Raj with common political, bureaucratic and military institutions, why then was the army not 'all-India'? Did not the fact that the army was drawn largely from a limited constituency prove it to be little more than a mercenary occupation force; an instrument of British repression?

A third function of the Army in India-perceived more abundantly in London than in Delhi-was as an imperial military reserve. India provided not only an immense reservoir of manpower but also a convenient, and cheap, repository for a quarter of the British army. The 75,000 or so British troops in India were paid for by the Indian taxpayer. The Secretary for War in London had to provide for them neither in the Annual Army Act nor in his departmental estimates. Few ministers were so fortunate. As for the Indian troops, they were employed in numerous colonial expeditions during the nineteenth century. But from almost the very beginning there was friction between the Indian and British governments over the question of paying for these soldiers. Although it was generally accepted that expeditions on the Frontier or in Burma should be borne upon the Indian establishment, the position was much less clear in the case of operations in Africa or China. The despatch of Indian troops to reinforce the British garrison in Malta in I 878 raised the whole constitutional question of Indian Army service overseas and inflamed Liberal anti-imperialists in parliament. W. E. Forster, from the opposition benches, questioned a policy which relied 'not upon the patriotism and spirit of our own people, but upon the power of our money bags, to get Gurkhas and Sikhs and Mussulmen to fight for us' 8 Even the popular parodists had a word to say on the matter:

We don't want to fight; but, by Jingo, if we do, We won't go to the front ourselves, but we'll send the mild Hindoo. ${ }^{9}$ Imperial necessity, nevertheless, prevailed over tender Liberal consciences. In I 882, after Gladstone had returned to power for his second administration, Indian troops were employed to augment the British forces in Egypt. Finance, however, continued to cause difficulties between Britain and India until in 1895 a Royal Commission was appointed to examine the problem. In April 1900 the Commission proposed a solution which was finally accepted by both governments in

${ }^{8}$ Lucas, The Empire at War, I, p. 54.

9 Oxford Dictionary of Quotations (2nd edn, London, 1953), p. I , n. 9. 
1902. Apart from such 'special cases' as might arise, it was proposed that India should bear primary financial responsibility for those geographical regions in which she had a 'direct and substantial interest'. Included among such regions were Egypt 'so far as the security of the Suez Canal is affected', Persia, the Persian Gulf and Afghanistan. ${ }^{10}$ Thus the matter rested until after the Great War when the Indian government once more began to question the financial basis upon which Indian troops were employed outside India.

Despite the extensive use of the Indian Army overseas during the later nineteenth century, it was not until I 898 that Indian troops were first employed in colonial garrisons. The strains which the South African War, a white man's war in which Indian troops were not used, made upon the imperial military system confirmed these early arrangements and by I9I 4 the Indian Army was being regularly employed for garrisons in Egypt, the Indian Ocean, Singapore and China. There was, however, an older tradition of recruiting soldiers in India for service in special local forces in colonies and protectorates both in Asia and Africa. Sikh contingents saw service in the African protectorates, and the Malay States Guides regiment was largely recruited in India. From I 892 to I 903 special service battalions were raised in India for service in Hong Kong and a battery of artillery was specially recruited for employment in both Hong Kong and Singapore. ${ }^{11}$ Although these special units for service in the empire comprised only a very small part of India's total contribution to imperial defence, after the Great War the Indian government was to put up a scheme for colonial garrison regiments, distinct from the Indian Army, to be raised in India. From the Indian point of view such a scheme made rendering charges to the imperial exchequer, for 'imperial' rather than Indian defence, more straightforward than British proposals simply to continue seconding battalions from the Indian Army proper.

There were, however, no financial quibbles when the empire went to war in August 19I4. By the end of October 19I4 two Indian infantry divisions were fighting in Flanders. At London's request six battalions were sent to East Africa and a rather larger force went to Egypt. In the early autumn a brigade was despatched to the head of the Persian Gulf in order to defend British interests in the area, especially the AngloPersian Oil Company's installations in south-west Persia. With the declaration of war against Turkey at the end of the same month, this

10 'Copy extract report of the Indian Expenditure Commission', India Office Records (IOR) $\mathrm{L} / \mathrm{F} / 7 / 783$. Quoted by kind permission of Controller of H.M. Stationery Office.

${ }^{1}$ Lucas, The Empire at War, I, pp. 123-4, 255. 
force was soon increased to a division. ${ }^{12}$ By the end of the war there were to be more than a quarter of a million Indian native troops in what became known as the Mesopotamian Command, covering Mesopotamia itself, Persia and detachments in the Caucasus and Transcaspian regions of south Russia. ${ }^{13}$ This figure was greater than the total number of Indian ranks serving in August $1914 .{ }^{14}$ During the war nearly $1,200,000$ Indians were recruited for service in the army. ${ }^{15}$ In October I 9 I 8 the Military Secretary of the India Office estimated that in the year ending I June 1919 'the normal pre-war recruiting figure for the Indian Army of about 15,000 men will have been increased to 500,000 '. ${ }^{16}$ As well as providing manpower the Indian government agreed early in the war to continue to bear 'the ordinary charges of the troops sent out of India which she would have had to pay had they remained in India', and subsequently agreed also to make a substantial contribution towards the 'ordinary' charges for the extra troops raised for the war. ${ }^{17}$ In I 9 I 7 , moreover, India made an outright gift of $£$ I 00 million towards the cost of the war-'nearly twice India's whole net revenue before the war'. ${ }^{18}$

India's greatest part in the war was played in the Middle East. In October 1918 over hall the troops in Mesopotamia were Indian and rather more than a third in Palestine. ${ }^{19}$ Throughout the war, moreover, India was exclusively responsible for providing all supplies and stores required by the troops, both British and Indian, in Mesopotamia. ${ }^{20} \mathrm{But}$ the Mesopotamian campaign also revealed serious administrative weaknesses in the Indian military machine. Kitchener's reform of the Indian Army a decade or so before the outbreak of war while enormously improving the mobility of the army had sacrificed administrative efficiency to this end, ${ }^{21}$ and nowhere was this to be more apparent than in

12 Lucas, The Empire at War, V, p. I8o.

${ }^{13}{ }_{26}, 067$ soldiers (combatants only). 'Strengths by arms of the expeditionary forces', 16 December 1918. Milner MS. (Bodleian Library, Oxford) dep. I 45 .

${ }^{14}$ Regular troops, I 59, I 34; Reservists, 34,767; Non-combatants (Labour Corps etc.) 45,660 ; Total, 239,561. 2 I November 1919, 'Memo. on the total contribution in men made and casualties suffered by India during the war'. PRO CAB. 24/70 G.T.6341.

${ }^{15}$ Combatants, 757,747; Non-combatants, 404,042. Ibid.

162 October 1918, 'Note on India and the war' by Gen. Sir H. V. Cox. Montagu MSS. AS/I/2/65 (Trinity College, Cambridge).

${ }^{17}$ c. October 1918 , 'Note on finance'. Montagu MSS. AS/I/2/56.

18 Ibid.

19 c. October 1918 , 'Note on military aspects'. Montagu MSS. AS/I/2/57.

${ }^{20}$ Govt of India, India's Contribution to the Greal War, p. 107.

${ }^{21}$ Philip Mason, A Matter of Honour: An Account of the Indian Army, its Officers and Men (Harmondsworth, 1976), p. 399. 
Mesopotamia which for the first two and a half years of the war was an exclusively Indian theatre of operations. From the beginning there were administrative difficulties and it was an almost total breakdown in support services which was in the most part responsible for the surrender in April I917 of General Townshend's division at Kut. Such was the Indian failure that for the rest of the war the control of military operations in Mesopotamia was transferred to the War Office in London, ${ }^{22}$ and so it was to remain following the Armistice. Thus, while India continued to supply much of the manpower and all of the matériel for Mesopotamia, the direction of military policy lay in London.

In the spring of I 9 I 9 the War Office took advantage of this agreeable state of affairs to canvass the idea that they should take over complete control of the entire Indian Army and incorporate it into a single imperial force. Edwin Montagu considered the scheme so 'idiotic' that he hardly thought it worth refuting. ${ }^{23}$ But the disasters of Mesopotamia had left their mark and Lloyd George appointed a committee, chaired by the veteran strategist Lord Esher, with a wide-ranging brief to examine the post bellum Indian Army. It reported in the summer of 1920 that 'the military resources of India should be developed in a manner suited to imperial necessities'. That being so, along with a number of much-needed internal administrative reforms, Esher recommended that the running of the Indian Army should be placed directly under the authority of the Chief of the Imperial General Staff (CIGS) in London. ${ }^{24}$ This dovetailed neatly in with the War Office opinion that 'the only sound and economical method of imperial defence is to regard the forces of any portion of the Empire as being available for use in any other'. ${ }^{25}$ But the idea was an anathema to Delhi. However successful War Office control had been in war-time Mesopotamia, by 1920 the concept was already archaic. It had been overtaken by events in India. No Indian government, let alone one struggling to introduce constitutional reforms, could accept such an outright subordination of Indian to imperial interests. In any case, the proposal foundered on the rock of finance. Chelmsford had pin-pointed the problem early in 19 I 9 when he insisted that 'so long as India pays,-and I do not suppose the War Office are going to propose to the English Treasury to take over the

\footnotetext{
22 Ibid., pp. 432-3; Lucas, The Empire at War, V, pp. 290-6.

${ }_{28}^{23}$ May 1919, Montagu to Chelmsford, Montagu MSS. IOR D.523, vol. 3, pp. $120-1$.

2422 June I920, 'Report of the Army in India committee, I919-20', PRO CAB. $24 / 112$ C.P. 1980.

25 June I 920, War Office to India Office, IOR L/MIL/7/19323.
} 
charges of the Indian Army,-India must control its own Army'. ${ }^{26}$ It was an understandable, if un-imperial, attitude.

At the same time as the War Office were proposing to assume overall charge of the Indian Army, they also unquestioningly assumed that India would continue to provide most of the men and material for the post-war imperial acquisitions in the Middle East. The Indian government, however, did not share London's happy confidence and soon began moving to reduce their commitments in the region. Early in December I 918 the Army Department in Delhi informed the India Office that 'in view of the extreme difficulty of our financial position and our own urgent needs', the 'drain both in money and material on the resources of India cannot any longer be met without the gravest embarrassment'. ${ }^{27}$ Throughout 1919 the Indian attitude hardened. In September Austen Chamberlain complained to Lord Curzon that at a recent meeting concerning military expenditure in Mesopotamia, the India Office's contribution 'was limited to a warm support of whatever the military desired, coupled with the condition that no part of the expense was to fall on Indian funds! ${ }^{28}$ Montagu for his part saw things rather differently and told Chelmsford in October:

I cannot rid myself of the obsession that a good many people here are trying to establish a routine of running up a heavy bill of costs over whatever item of Imperial policy happens to suit them at the moment, and sending in the account to India as an afterthought. ${ }^{29}$

From India the Viceroy moved to the offensive. 'You have of course by this time realised', he wrote to Montagu in December I9 19 ,

that one of our great difficulties is the keeping of some one hundred and eighty thousand Indian troops in Mesopotamia, the Black Sea, Palestine, France, East Persian Cordon, Bushire and elsewhere. It will be extremely difficult for our Army authorities to reorganise our Army in India so long as such a large proportion of the Indian Army is maintained outside India. I must point out also that India in this way is being exploited by the War Office because they find that they can maintain Indian troops abroad without those extremely objectionable questions in Parliament which would be asked if they were British and not Indian forces. ${ }^{30}$

\footnotetext{
${ }^{26}$ I 2 February 1919, Chelmsford to Montagu, Montagu MSS. IOR D.523, vol. 8, p. 26.

${ }_{27} 2$ December 1918, Viceroy to Secretary of State for India (S. of S.), Chelmsford MSS. IOR E. 264 , vol. 9 , pp. $467-8$.

${ }^{28}$ i 7 September 1919, Chamberlain to Curzon, Curzon MSS. IOR F.1 $12 / 209$.

29 I 7 October 1919, Montagu to Chelmsford, Montagu MSS. IOR D.523, vol. 3, p. 218.

${ }^{30} 3^{\text {I }}$ December 1919, Chelmsford to Montagu, ibid., vol. 9, pp. $4^{1} 3^{-1} 4$.
} 
This was the rub, for the Montagu-Chelmsford reforms then being introduced aimed to introduce an element of popular sovereignty into India. The Government of India Act (1919) provided for the establishment of an Indian legislative assembly which would certainly give Indian politicians an ample opportunity to ask 'extremely objectionable questions'.

Delhi's unwillingness to meet what London saw as justifiable military obligations in the Middle East was also confirmed by unrest, both internal and on the frontiers. Until early 1922 domestic security posed serious problems. The largely bi-communal Congress agitation, the Muslim Khilafat movement and the Moplah rising in August I 92 I all served to restrict the imperial manoeuvrability of the Indian Army. General Dyer's Cromwellian peacekeeping methods at Amritsar in the Punjab, and their subsequent approval by many Britons in India and at home, did much to exacerbate Anglo-Indian relations. In its turn this made the Indian government yet more nervous of inflaming domestic political opinion by committing Indian revenues to expensive imperial military co-operation. On the Indian periphery the problems were more specifically military. The Kuki-Chin rebellion in Burma, which had broken out in 1917 , was not finally quelled until the spring of $1919,{ }^{31}$ while across the sub-continent the Frontier was far from quiet. The 'Third Afghan War' from May to August Igrg imposed substantial strains on an Indian Army whose resources had been 'depleted by a long war' and came at a time when internal disturbances had necessitated 'the temporary redistribution of troops'. ${ }^{32}$ In October I9r9 Delhi was reluctantly forced to consider operations against hostile Waziri tribesmen. Despite their wish to keep the action as limited as possible, they found it necessary to undertake 'extended operations' and the area was not pacified until the beginning of September $1920 .^{33}$

It was against this background of internal and peripheral disorder that London seemed incessantly to call for Indian troops to serve in imperial garrisons. These demands reached a peak in the summer of I 920 when the Mesopotamian rebellion broke out. Although there were already some 50,0oo Indian troops in Mesopotamia, following the outbreak of violence in August the War Office arranged for an addi-

${ }^{31}$ June 1919, 'Despatch on the operations against the Kuki tribes of Assam and Burma', PRO W.O.106/58.

${ }^{32} 20$ August 1919, Viceroy to S. of S., Chelmsford MSS. IOR E.264, vol. I1, pp. $188-9$

${ }^{33} 6$ October I919 and 23 March 1920, ibid., pp. 321-2 and vol. 12, pp. 274-5; 4 September 1920, ibid., vol. 13, pp. $214^{-15}$. 
tional nineteen battalions to be sent as reinforcements from India. ${ }^{34}$ In view of the emergency these troops were not begrudged by Delhi. London, indeed, had been assured on 7 July that in the event of a Mesopotamian crisis arising, and the despatch of reinforcements becoming absolutely necessary, you may rely on us to do our utmost to render such military assistance as we are able from the resources at our disposal'. ${ }^{35}$ The demands made by the imperial government in respect of the Mesopotamian crisis, however, were of such magnitude that they seem, for the first time, sharply to have brought home to the Indian government the full extent of the imperial military burden which London expected them to share. From this point on the Indian government began to back-pedal strongly on the supply of overseas garrisons from the Indian Army and to argue forcefully that their military and financial responsibilities extended little further than the frontiers of India itself.

On 3 September 1920, Montagu circulated to the cabinet an important telegram from the Viceroy:

Recent demands received by us for reinforcements for Mesopotamia on a large scale [it read] have forced us to consider the whole question regarding supply of overseas garrisons from Indian Army.

It would appear that His Majesty's Government is counting on India to provide a quota of the permanent garrisons of the mandatory territories in addition to certain colonial garrisons, including Aden, the Gulf ports and consular escorts in East Persia. We have received no direct information that His Majesty's Government desires us to undertake this liability: but have received an estimate which shows that, on present figures, this force will include, among other details, 4 cavalry regiments, 1 cavalry troop, Io Sappers and Miners Companies, $39 \frac{1}{2}$ Infantry and Pioneer battalions, I signal troop and 4 signal companies. It is possible that this estimate is not final. We invite attention to the fact that we have not been consulted as to probable political effects in India of accepting an engagement of this magnitude. It appears advisable to us, however, to warn you at once of our views on this aspect of the question.

Chelmsford went on to describe that public opinion in India generally opposed the extensive use of Indian troops overseas and regarded India as being exploited, especially since no similar request for troops had so far been made on the dominions. ${ }^{36}$ The Indian government, moreover, was at pains 'definitely to emphasise' that they 'could not accept an obligation to supply permanent overseas garrisons to mandatory territories' and they did not consider that 'the Indian Army should be

${ }^{34}$ Sir Aylmer Haldane, The Insurrection in Mesopotamia, 1920 (Edinburgh and London, I922), p. 64; 26 August 1920, 'Military policy in Mesopotamia', copy of telegram from S. of S. for War to GOCinC Mesopotamia, PRO CAB. 23/ I I C.P. 18 I 4 .

357 July 1920, Viceroy to S. of S., Chelmsford MSS. IOR E.264 vol. 13, p. 24.

36 The dominions were to be approached on 18 September 1920. 
required to provide large overseas forces'. ${ }^{37}$ Later the same month Montagu circulated a paper containing a selection of articles culled from Indian journals, each one quite opposed to the extensive use of the Indian Army overseas. 'I fear that the position is very bad', he noted, 'because they can be taken to be the first mutterings of a storm'. ${ }^{38}$ As had been the case before the war, the Indian government displayed a marked reluctance to slip easily in with London's plans for the imperial disposition of the Indian Army. This prudence was particularly understandable in the immediate post-war period, preoccupied as Delhi was with introducing domestic political reforms.

The telegram of 3 September was a straightforward reversion to India's pre-war position, arguing as it did that the Indian Army had no obligation to supply troops for permanent and extensive overseas garrisons. The principle, moreover, that India should not pay for such garrisons had, in Indian eyes, long been established. In January I 9 I 9 , Montagu told Chelmsford: 'I have pointed out by law and practice Indian revenues are not called upon to maintain an army in excess of Indian requirements on a reasonable estimate of same, and as at present advised I am strongly opposed to any alteration of this principle'. ${ }^{39}$ The principle was applied frequently. In April I 920, Chelmsford noted that 'in order to meet the overseas requirements of His Majesty's Government', especially in the Army of the Black Sea, extra units might need to be maintained in India. 'We assume', he added, 'in that case the cost of additional units . . . will be charged to His Majesty's Government'. ${ }^{40}$ In December 1920 the Indian government announced that it would cease contributing towards the cost of the South Persian Rifles (an irregular force with British officers) at the end of the year since 'we have consistently protested against payments being made from Indian revenues on account of South Persian Rifles, and have maintained that this expenditure cannot in fact legally be met from Indian revenues'. ${ }^{41}$ When the question arose of sharing the costs of the Malleson Mission in east Persia in February 1921 , the Viceroy objected to India taking any share in the expenditure on the grounds that the Mission 'had a definite military objective of a purely Imperial character' ${ }^{42}$

The problem of Indian Army service 'ex-India' was accentuated by

${ }^{37} 3$ September 1920, 'Supply of overseas garrisons from the Indian Army'. CAB. 24/ I II C.P. I 844 .

38 6 September 1920 , ibid., C.P. 1871 .

3929 January I 9 rg, S. of S. to Viceroy. Chelmsford MSS. E.264, vol. Io, P. 39.

407 April 1920, Viceroy to S. of S., ibid., vol. 1 2, p. 311 .

41 I 7 December 1920 , Viceroy to S. of S., ibid., vol. I3, p. 5 I I.

42 I9 February 1921 , Viceroy to S. of S., ibid., vol. 14, p. I68. 
internal political pressures to such an extent that by $\mathrm{I} 92 \mathrm{I}$, 'owing to political changes in India', Delhi declared that the 'standing arbitration agreement' of i 902 was no longer in force. 'The determining factor', they averred, 'in any ... dispute under present conditions must be the state of native opinion and feeling' ${ }^{43}$ In February 192 I the Montford reforms were inaugurated, providing Indians with a new opportunity to influence decisions in Delhi. In addition to creating a legislative assembly, three-quarters of which were elected, the reforms established a convention that three of the eight-member Viceroy's Council should be Indians, who were thus admitted to the highest echelon of the administration. ${ }^{44}$ But although a measure of representation had been introduced into the central government, the Viceroy and his council remained responsible to the British cabinet and constitutionally London retained the final say in major matters of policy. Despite this the CIGS, Sir Henry Wilson, was not reassured by the changes. Montagu and Chelmsford, he felt, had 'lost control' and they 'now dare not impose the extra taxation necessary' to maintain the size of the British garrison in India. 'The . . . Council will, before long', he continued, 'refuse to allow Indian Native troops to serve outside India! And then!" ${ }^{45}$ He was not altogether wrong. Although military expenditure was excluded from legislative vote under the 19 I 9 Act, the levying of taxation was not. The legislature could therefore exercise an indirect influence on military affairs. In addition to reforms at the centre, the igig Act devolved considerable powers -including budgetary ones - to new provincial assemblies. But Delhi had to fund these additional power-centres, and fund them generously if Indian politicians were to be kept sweet. This meant retrenchment in central expenditure. To the civil administrators of the Raj, military spending - 'rather more than $32 \%$ of the whole revenue of the Country'46 - was an obvious area for economy. Either the size of the army had to be cut or an imperial subsidy gained for ex-India commitments. Neither option appealed to London. India's strategic value to the empire depended to a very great extent on its being a military milch cow. The Indian Army was only a genuine imperial asset so long as it was cheap. This, then, was the dilemma facing Delhi. Political control in India could only, it seemed, be bought at the cost of

${ }^{43}$ February $192 \mathrm{I}$, Report of committee on Indian charges for forces in east Persia, PRO W.O. $32 / 5808$.

${ }_{44}$ Percival Spear, A History of India, vol. II (Harmondsworth, 1970), pp. 185-8.

45 i 1 January 192 I, Diary of Sir Henry Wilson, Wilson MSS. Quoted by kind permission of the Trustees of the Imperial War Museum.

${ }^{46} 9$ January 192 I, Lord Rawlinson (CinC India) to Sir Henry Wilson, Wilson MSS. File ${ }_{3} \mathrm{C}$. 
the imperial fire brigade. But this was a price which London was reluctant to pay.

When Lord Rawlinson became Commander-in-Chief in India during the late autumn of 1920 , he was immediately presented with this dilemma. 'As we both foresaw before I left', he wrote to his old friend Sir Henry Wilson, 'there is bound to be a pretty severe fight over finance. Certain of my honourable colleagues on the Viceroy's council are endeavouring to bring pressure on me ... to reduce the strength of the army and thus avoid the necessity of imposing further taxation'. ${ }^{47}$ A few days later he told Wilson that he was determined not to take

the responsibility for making sweeping reductions in the fighting forces in India ... All the members of the Viceroy's council that I have seen so far are terrified at the idea of imposing further taxation. They say that the matter will have to be brought before the new Legislative Assembly when it meets and that to start with a demand for raising further monies for the army would be a fatal political step, for it will put in opposition not only the present extremists in this country but also a large proportion of the moderates. ${ }^{48}$

During the winter of 1920-2 I the Indian government scoured the military budget for possible savings. In January I 92 I Rawlinson reluctantly suggested a reduction in the British establishment of 6,ooo troops to 59,000 in all. But this would not be possible before 1922. As it was, the British contingent was under strength and required an actual increase of 7,000 men even to reach the proposed reduced total. ${ }^{49}$ His proposal provoked an immediate response from London demonstrating clearly that imperial considerations still took priority over Indian. 'Recruitment and organisation of British Army', wired Montagu, 'takes account of fact that India has for many years maintained certain minimum strength of British troops'. The question of reducing the British garrison raised a vast number of difficult and complex problems and would take years to sort out. ${ }^{50}$

So the government went to the assembly with little to offer other than an assurance that they had been pressing London for the early return of Indian troops serving overseas. But their anxieties were not realized. When the assembly came to debate military affairs during its inaugural session in March $192 \mathrm{I}$, although there was some general criticism of the high level of military spending, by and large their opinion coincided

${ }^{4} 25$ November 1920, Wilson MSS., ibid. Rawlinson had landed at Bombay on 21 November.

${ }_{48} 3$ December 1920 , Rawlinson to Wilson, Wilson MSS., ibid.

49 18 January 1920, S. of S. to Viceroy, Chelmsford MSS., E.264, vol. 14, p. 50.

5022 January 1920 , Viceroy to S. of S., ibid., p. 33. 
with that of the administration. The underlying assumption of the Esher report that a unified imperial command be established was repudiated and the assembly affirmed that 'the purpose of the Army in India must be held to be the defence of India against external aggression and the maintenance of internal peace and tranquility'. ${ }^{51}$ The Viceroy was agreeably surprised by the moderate tone of the debate and reported to London (in contrast to his views of the previous September) that 'there is strong feeling in country in favour of employment of Indian troops on garrison duty over-sea with Government of India's permission', but subject always to the important condition 'that no additional expense is caused thereby to Indian revenues'. ${ }^{52}$ Rawlinson thought the assembly's attitude one of 'pleasing moderation' and the budget, including some extra taxation to fund army spending, passed through 'without much serious difficulty. ${ }^{53}$

One of the factors regarding internal security which the British rulers of India never considered was that whatever 'war games' the general staffs in Delhi or London might play, to plan for a major rebellion in India was quite unrealistic. This is not at all to suggest that such an occurrence was either unlikely or unanticipated-Rawlinson regarded it as 'a practical certainty' that there would be a war 'either within or without our frontiers during my term of office' ${ }^{\text {54 }}$-but simply to note that the British had not the power to defeat a serious all-India rising. Two-hundred-and-thirty thousand troops and one-hundred-andninety thousand police-more than three-quarters of which were Indians themselves-would not go far in a country of 319 million people. Lord Salisbury had been of the opinion that British rule in India rested not on force but on consent ${ }^{55}$ and this was just as true in 192 I as it had been in 1874 . When considering the possibility of internal unrest Montagu warned the cabinet in October I 920 that

if any of my colleagues think of the isolation of Europeans in India, of the smallness of the British force in India, and realise that a campaign comparable to the Sinn Feinn campaign in Ireland would be almost impossible to deal with except by punishment and revenge, certainly not by prevention, they will understand the danger of the situation which has been caused [in the Punjab]

51 zo March 192 1, Viceroy to S. of S., ibid., pp. 293-4; Legislative Assembly debates, vol. $\mathrm{I}$, no. 15 , enclosed in IOR $\mathrm{L} / \mathrm{MLL} / 7 / 10822$.

526 May $192 \mathrm{I}$, Viceroy (Army dept.) to S. of S., pt II, IOR L/MIL/3/2513, p. $95^{8}$.

53 zo March I 92 I, Rawlinson to Lord Derby, Derby MSS. IOR D.605/5.

54 I September I920, Rawlinson to Gen. Sir Charles Monro (CinC India I9 16-20), Rawlinson MSS. 5201/33/22. Quoted by kind permission of the National Army Museum.

${ }^{55} \mathrm{~S}$. Gopal, British policy in India $1858-1905$ (London, 1965) p. 65. 
by the assertion of a force we do not in reality possess in preference to the doctrine of goodwill. ${ }^{56}$

It is to his credit that Lord Reading, who became Viceroy in April I 92 I, recognized the futility of unambiguous repression and that throughout his first year in office, the 'peak year' of Hindu-Muslim agitational unity,${ }^{57}$ he displayed such admirable restraint towards the nationalists, flying frequently in the face of advice from London, Army headquarters and the majority of the provincial governors. ${ }^{58}$ The mistakes of the Punjab in I9I9 were not repeated, Delhi courted the moderate Indian politicians who were prepared to work the new constitution and the non-cooperation campaign was left to run out of steam on its own, unprovoked by any official over-reaction. In February 1922, when the national protest threatened to descend into violence itself, Gandhi called off the campaign and mass political action in India ceased for half a decade. ${ }^{59}$

Despite the Legislative Assembly's compliant attitude, the Viceroy still believed that Indian military policy needed to be re-assessed in view of the changed political circumstances. In May I 921 he appointed a committee under Rawlinson to examine 'Indian military requirements'. ${ }^{60}$ The four Indian members of the committee demanded a substantial reduction in the number of British battalions earmarked for 'internal security'. Rawlinson had reluctantly to concede some reductions and thereby raise the proportion of Indian to British troops in India:

I was unable to resist the pressure when it came to weighing the fact that we had 28 Brit. Battns and only 21 Indian in Internal security. [He wrote in his journal.] It was impossible to defend these proportions-I have agreed to abolish the Ratio. There is no need for it nor can you defend such a basis of arrangements in present Indian conditions, though after the Mutiny there may have been something in it-Now there certainly is not for we have decided to trust the Indians to lead them to self governt. and we cannot therefore justify an Army of occupation. ${ }^{61}$

The final recommendation of the committee was for a reduction of three British cavalry regiments and five battalions of infantry, more than

${ }^{56}{ }_{15}$ October 1920 , 'The state of India'. CAB $24 /$ i 12 C.P. 1987.

${ }^{57}$ R. J. Moore, The Crisis of Indian Unity 19I7-40 (Oxford, I 974), p. 21.

58 D. A. Low, 'Government of India and the First Non-co-operation Movement 1920-22', in R. Kumar (ed.), Essays in Gandhian politics (Oxford, 1971), pp. 305-16.

${ }^{59}$ Ibid., pp. 315-18.

60 1o May 192 I, Rawlinson to 'Douglas' (Haig?), Rawlinson MSS. 5201/33/22.

61 Io July I 921 , 'Indian journal', ibid., $5201 / 33 / 23$. 
Rawlinson would ideally have wished, ${ }^{62}$ but subject to the proviso that any 'deterioration in the internal or external situation' might necessitate a modification of this proposal. The committee also favoured the 'adoption and publication . . . of a definite policy of Indianisation of Indian Army'. ${ }^{63}$

The Rawlinson committee's proposals for troop reductions were modest enough, but within a fortnight of their first being sent to London, disturbance among the Muslims of the Madras Presidency-the 'Moplah rebellion'-obliged Delhi to postpone consideration of the committee's report. ${ }^{64}$ Although mopping-up operations continued until the second half of 1922 , the back of the rebellion was broken by November I $92 \mathrm{I}^{65}$ and the military authorities could once more concentrate their attention on the problem of economy. This gave Rawlinson no pleasure because demands for retrenchment had escalated since the summer and it seemed likely in November that the Legislative Assembly would be satisfied with nothing less than a reduction of twenty or twenty-five British battalions. 'We cannot possibly accept any decision of this kind', wrote Rawlinson to Wilson, 'for the Viceroy and I fully realize that it would endanger the safety of the country'. ${ }^{66}$ But some concession was necessary if only as a gesture towards Indian opinion in order to ease the passage of the budget in the spring. In February 1922, therefore, Delhi told London that they hoped not only to implement the reductions in British troops recommended by the Rawlinson committee but also to buy off the Indian politicians through adopting its Indianization scheme.

We have, [they telegraphed] in any event, a very difficult situation to meet. With political situation you are familiar. On top of this we are confronted with necessity of imposing, for the second year in succession, very heavy additional taxation. That taxation will inevitably be challenged as being due to heavy expenditure connected with maintenance of our Army. It is our considered opinion that, in order to avoid a complete breakdown, it is essential that we should be allowed to make the two announcements [of reductions and Indianization] ... Unless we receive your permission to do so, consequence must be, we consider, grave, involving serious risks of complete breakdown of the Reform Scheme, and rendering administration of this country most difficult. ${ }^{67}$

62 I 2 July I $92 \mathrm{I}$, Rawlinson to Wilson, Wilson MSS. File ${ }_{3} \mathrm{E}$.

${ }^{63} 2$ I July I 921 , Viceroy (Army dept.) to S. of S., pts I and 2. IOR L/MIL/3/25 I 3 P. I5I2.

${ }_{64} 4$ August I 921 , Viceroy (Army dept.) to S. of S. IOR L/MIL/3/2513 p. I631.

${ }^{65}$ Sir Percival Griffiths, To Guard my People: The History of the Indian Police (London \& Bombay, 1971 ), pp. 288-92; A. C. B. Mackinnon, 'The Moplah rebellion I $921-22$ ', in Army Quarterly, viii (1924), pp. 260-77.

${ }_{66}^{63} 23$ November 1921 , Rawlinson to Wilson, Wilson MSS. File ${ }_{3} \mathrm{~F}$.

${ }^{67} 6$ February 1922, Viceroy (Army dept.) to S. of S., IOR L/MIL/3/2514 no. 1121. 
There was little sympathy for the Indian position in London. A cabinet committee met to discuss the Viceroy's requests on io February and came out very strongly against any reduction in the British garrison but was less unanimous on the question of Indianization. Lloyd George declared that he thought all the Englishmen in India had got 'cold feet and that they must be cured of their feeling of discouragement'. ${ }^{68}$ Montagu had little to offer when he sent the cabinet's reply to Delhi. No 'further reduction' of the British troops in India could be sanctioned. The general feeling in London was that taking into consideration 'the frontier of India, its size, the importance of its communications and the political conditions', the Indian government had 'no troops to spare'. The Rawlinson committee's Indianization proposal could not be accepted and, finally, the cabinet absolutely forbade the publication of any part of the committee's report for 'it could not fail to reveal differences of opinion between your Government and His Majesty's Government which at all costs must be avoided'. ${ }^{69}$ On the same day, Montagu sent Reading a second telegram on 'the fundamental principles of Indian Government':

Reports are constantly reaching England of a widely held belief, not only among Indians but among Englishmen, that we regard our mission in India as drawing to a close that we are preparing for a retreat. If such an idea exists, it is a complete fallacy, and its continued existence can only in itself lead to a decline in morale among the services and to intensified challenges to our authority ... The security of the country from dangers without and within upon which depends the capacity of its Government to fulfil its primary duties can only be ultimately guaranteed by the Army in India. With regard to it we cannot take any steps which would compromise our position. If therefore we find it impossible to reduce the size of the Army or to accept a programme of Indianisation which we are compelled to believe would be prejudicial to its efficiency, it is because we believe that an acceptance of such proposals would not only lend colour to the dangerous belief in a policy of retreat, but must directly hamper us in the exercise of the functions with which we are entrusted. ${ }^{70}$

The Cabinet, of course, were in a good position to demand a thoroughgoing application of 'empire' in India since they could safely leave its primary application to their agents in Delhi and perhaps not necessarily be implicated in the possible failure of such a policy. Besides, to take an imperial 'hard line' with Delhi could scarcely do any harm to Lloyd George's flagging reputation on the Unionist backbenches.

${ }^{68}$ to February 1922, diary of H. A. L. Fisher, Fisher MSS. (Bodleian Library, Oxford), Box 8A.

${ }^{69}$ is February 1922, S. of S. to Viceroy, IOR L/MIL/3/2534 M.1348/1 922 no. I.

${ }^{70}$ lbid., no. 2. 
Lord Rawlinson, although he had reluctantly come to the conclusion that Indianization must eventually happen 'whether we like it or not', ${ }^{71}$ was not displeased with London's refusal to allow any reduction in the British garrison. In July I 922 he told the Viceroy that there was 'the strongest argument of all for not reducing the British garrisons in India, and nothing will induce me to agree to it even with bankruptcy staring us in the face. But', he added, 'we must both reduce expenditure and increase taxation if there is to be any hope of balancing our next budget'. ${ }^{72}$ The army vote, moreover, still offered the richest field for economy. 'We cannot get away from it', wrote Reading to Peel, Montagu's successor at the India Office, 'that no substantial reduction can be made in expenditure unless military expenditure is tackled'. ${ }^{73}$ But to cut military expenditure meant reducing the number of troopspreferably British from Delhi's point of view - and that was generally unacceptable in London, not only for internal security reasons. When Worthington-Evans was considering the Rawlinson committee recommendations in the summer of $192 \mathrm{I}$ he noted that the reduction of British units in India would throw those units

on to the Imperial Budget, or, as the only alternative, force us to disband them and so to weaken the armed strength of the Empire as a whole without any relief to the British taxpayer . . . It is in my opinion a question for special consideration whether the Indian taxpayer is to be endowed with this priority of right to the savings to be made by weakening the Empire as a whole. ${ }^{74}$

Clearly the Secretary for War still regarded the Army in India as a subordinate imperial military organization, free to be ordered about the world at will by London-as had been the case during the war. But Worthington-Evans was wrong. It was as nasty a case of hubris as one might encounter for him to believe that the British taxpayer, or even the British cabinet, was better qualified than the Indian to direct Indian military expenditure. He was foolish also to assume in I92 I that Britain still had the power (if indeed she had ever been so graced) fully to control her Indian empire, and arrogance without power is just the sort of thing which gives hubris a bad name.

${ }^{71} 2$ I July I92 I, Rawlinson to Wilson, Wilson MSS. File ${ }_{13} \mathrm{E}$. A scheme of limited Indianization was introduced in March 1923 . See V. Longer, Red Coats to Olive Green (New Delhi, 1974), p. r 94; Mason, A Matter of Honour, pp. 453-66.

7228 July 1922, 'Indian journal', Rawlinson MSS. $5201 / 33 / 22$.

${ }^{73} 3$ August 1922, Reading to Peel, Reading MSS. IOR E.238, vol. 5, p. 112.

${ }^{74}$ August I921, 'Future military expenditure'. PRO CAB. $27 / 164$ G.R.C.(D.D.)8. 